\title{
THE PROBLEM OF LONG TERM AND EQUITY CAPITAL $\dagger$
}

\author{
WALter C. LouchHeim, JR.*
}

\section{INTRODUCTION}

It must be clear that no satisfactory solution will be found to the problem of providing small business with capital until it is projected in the context of the more extensive problems of full production and employment with which it is functionally related. Yet the problem of small business has been generally treated in relatively complete isolation from these more fundamental subjects. This treatment has led, in the opinion of the writer, to sterile proposals for the providing of capital to small business. This article will critically evaluate recent discussions of the financing of small business and current suggestions for providing it with capital, and offer an alternative approach. This analysis is based upon the following premises:

I. That to date small business has not proved its case. By this is meant, not that there is no financial problem for some small businessmen, but that it is still open to question whether the aggregate of these problems is sufficiently widespread and meritorious to constitute a national problem or call for action by the federal government; that the research, investigation and discussion up to the present is not conclusive on this point.

2. That the necessary and sufficient conditions of whatever small business financial problems there may be are not to be found within the small business area where inquiry has been almost exclusively directed. But that these causes could have been found within the private banking system, that they are primarily of a psychological order stemming from the habits and attitudes of commercial and investment bankers in the principal financial centers as well as in regional areas, and that the stiff price asked by the bankers for small business accommodations results from these attitudes and is a much more important cause of the shortage of such accommodations than the availability of lendable funds.

3. That the plans, programs, bills for Congressional action, etc., which have been proffered as solutions for the problem are panaceas with scant hope of success

t The views expressed in this article are entirely those of the writer and are not to be taken as expressing the views of any member of the Securities and Exchange Commission or of its staff.

* A.B., 1921, Harvard University. Investment banker, 1921-1931. Staff member of the Securities and Exchange Commission since 1934, and at present Assistant Director of its Trading and Exchange Division. Adviser to the United States Delegation at the International Monetary Conference, Bretton Woods, I944. 
either because they fail to recognize the fundamental causes of the problem as residing in the banking system or because they fail to relate the small business problem to the more comprehensive one of which it is only a part, or for both reasons.

These premises will be further elaborated in the course of this discussion, and the conclusions drawn from them, that in order to solve the problem of small business financing through private instrumentalities there is required a complete revision of the relationship of American banking institutions to the economic decisions and activities of the national and international economy; that there is little probability for expecting such a revision without a complete reorientation of the attitudes of bankers and public investors which in its turn is improbable; and that what is therefore required is a public agency which can be sufficiently insulated from the predisposition for accepted financial standards to insure the full employment of its authorized resources. Finally a program will be offered for discussion which will avoid what appear to be the shortcomings of other plans and proposals, and which will relate the financing of small business to the larger objectives of full production and employment; that is, to the total and organic economy to which it belongs and can contribute bountifully.

\section{I}

Following a message from President Roosevelt the Congress by joint resolution created the Temporary National Economic Committee on June 16, 1938. This Committee was authorized and directed, "to make a full and complete study and investigation with respect to the concentration of economic power in, and financial control over, production and distribution of goods and services." One of the most impressive results of the Committee's studies and investigations was that of the problems of small business.

In the course of its study of the problems of small business, considerable emphasis was devoted to the financial aspects. These studies touched upon subjects such as the current financial position of small business, the banking policy and the needs of small business, governmental aids and their limitations. In the summary and conclusions of their report covering these studies, the authors of the report state: 1

"it must be recognized that by and large, the efficiency of operation is only one factor in the problem of small business, and a factor moreover not independent of the ability to obtain funds when most needed. Financial strength itself is an important factor in business success, especially during an era of severe business contractions and slow recovery. The firm that cannot tap the community's supply of long term capital except at high cost, and that cannot rely upon an immediate short term credit when opportunity knocks, is evidently at a disadvantage for that reason alone. The role of capital and credit in business expansion and success should not be underestimated. Whatever other causes may have contributed to the weakness of small business, this may be recognized as an essential factor."

${ }^{1}$ T.N.E.C., Problems of SAcall Business (Monograph No. 17, 1941) $24 \mathrm{I}$. 
The authors went on to appraise methods by which the unfilled financial needs of small business might be met and concluded that, "since small business cannot obtain needed capital through existing facilities, the dilemma can best be solved by the government."

While the value of the contribution made to the small business problems by the T.N.E.C. must be appreciated the circumstances under which its studies were made condition its applicability to the situation which is now presented. The study was made during the years 1938 and 1939 in which the country was suffering from a continuation of the sharp decline in production and employment that began in the latter half of 1937 . The prospects looked very bad. At that time no one could have foreseen the renaissance and resurgence of business activity and employment that ensued from the defense program and the prosecution of the war. Those who studied the situation prior to the war were naturally impressed by the depressed state of the economy and this conditioned many of their judgments and directed to a large extent the course of their inquiries. We are facing a far different present and future from that of the pre-war days. Ours is the problem of preventing a recurrence of depression conditions. Theirs was the problem of how to emerge from such conditions.

In spite, however, of this unavoidable drawback it should be said in fairness to those who participated in the T.N.E.C. investigation that they seem to have had a far better view of the small business problem in its proper context and in its relationship to the larger social and economic problems of the nation than those who have continued the study.

Among the several Congressional hearings and investigations on subjects in which small business has been involved, perhaps the most extensive has been that conducted by the "Special Committee to Study Problems of American Small Business of the Senate." This Committee was established in r94r, and in the approximately four years since then it has devoted 97 days to hearings. According to a report of this Committee, ${ }^{2}$ it has published 46 volumes incorporating the results of these hearings plus 18 monographs, 8 reports, 5 committee prints, 3 sub-committee prints and 4 public laws, all incorporated in over 8,000 pages of printed matter. The Committee is divided into 6 sub-committees and employs a staff of more than 25 persons. As may be expected the activities of this Committee have ranged throughout a variety of problems confronting the small business situation. To date, however, the Committee has admittedly not found a definite and long term solution to any of these problems. Among the subjects upon which it has heard witnesses have been the difficulties encountered in the obtaining of funds for capital purposes as well as for short term financing.

Reviewing the extensive testimony and documentation on this problem there is the impression that in spite of its good will the Committee has not approached this

\footnotetext{
2 Senate Small Bustness Committee-Its Record and Outzoox, Sen. Committee print No. 1, 79th Cong., Ist Sess. (Jan. 29, I945) 30-32.
} 
subject from the right direction. It has heard many stories which develop the unsatisfied financial need of the small entrepreneur. It has given the impression of a sincere sympathy for these needs but it has failed to make a genuine examination of the banking mechanism which is so fundamentally responsible for the picture that it has drawn. Numerous instances have been cited to the Committee of the obstacles which applicants have met and the high prices for credit which were demanded of them, but no attempt has been made to confront the purveyors of the funds with this situation or to examine them to determine why they have insisted over the course of years upon demanding such onerous terms during a period of generally easy money conditions. As a result of this oversight the legislation sponsored by the Committee has been almost completely silent as to any remedy for the exorbitant cost of financial accommodations to small business and as a further result the remedies propose continued reliance upon the private banking system for their effective performance. Had the Committee been better informed as to Amercan banking practices it is questionable whether it would have placed such confidence upon private financial institutions whose record in the field of small business financing, if examined, would seem to make such reliance at least debatable.

Another aspect of the Senate Committee's approach to the problem of small business is the almost complete silence with respect to the integral relationship between it and the problems of full production and employment. This is all the more remarkable in view of the fact that the Chairman of the Senate Small Business Committee is Senator James E. Murray of Montana, who is also Chairman of the Sub-committee on War Contracts of the Committee on Military Affairs. It was this latter committee which on December 18 , I944, issued a remarkable report ${ }^{3}$ on full production and employment incorporating the Full Employment Bill of 1945 which was subsequently submitted to the Congress by Senator Murray. In this bill there would seem to be an effective approach to the problems of the small business as well as to other problems confronting our post-war economy. What is remarkable is the fact that the Senate Small Business Committee has not subsumed its problems under these larger subjects to the solution of which it might substantially contribute.

In discussing the flow of investment capital toward the expansion of existing small enterprises and the launching of new ones the recent report of the Senate Small Business Committee states: "This is much more than a financial problem. It is an aspect of the fundamental problem of holding the way open for small business to expand as a means of keeping our whole economy in full production and employment." This is all that we find in the Committee's report on the relationship of small business to full production and even this statement is qualified by the further statement that although the Committee has devoted its attention to the role of small business in American life, "it is not implied that this important segment of business

\footnotetext{
3 Year-End Report of the War Contracts Subcommittee to the Committee on Military Afrairs (Senate), 78th Cong., 2d Sess. (Dec. 18, 1944).
} 
should have any favored treatment at the hands of government." The attitude here expressed seems hardly to be consistent with the purposes of the Full Employment Bill of 1945 in which is included a provision for government expenditures, to the extent that private investment is insufficient to provide a full employment volume, for several purposes including, "specific programs for assistance to business enterprises, particularly small business enterprises."

Outside the government area it is interesting to note that commercial as well as investment bankers have evidenced an aroused interest in the small businessman. Without detracting from the sincerity of this interest it may be opined that it was stimulated to no little extent by the public reception of the activities of the Senate Small Business Committee and other similar public investigations. The American Bankers Association has formed a Post-War Business Credit Commission which has looked into the matter of the availability of short term credit to small business and has submitted a recommendation. This calls for the formation of bank credit groups. The aim of these groups is to provide an additional source of credit for small and medium sized business enterprise through participation in loans originated by local banks which are unable to handle the credits alone. The American Bankers Association states that, "The bank credit groups are being formed in order to assure that every competent man, firm or corporation that needs bank credit for some constructive purpose will get it." amount of credit which will be made available by these groups will be about $\$ 500$ million and while this sum does not appear to be very large to the American Bankers Association it is its feeling that "it would be sufficient to cover participations with local banks in a very large number of loans to small business." The interpretation of such words as "competent" and "constructive purpose" in this statement of objectives will probably qualify the value of this proposal to no little extent, perhaps even more so than the actual amount at the disposal of the credit groups.

Several representatives of the investment banking industry have also been looking into the problem of supplying capital funds to small and new ventures. In a recent address to the National Association of Securities Commissioners, ${ }^{5}$ Mr. Ferdinand Eberstadt of the investment banking firm bearing his name, frankly stated that capital for small business "is practically unavailable and credit only slightly more accessible." He contrasts this with the superfluity of funds available to the large seasoned corporations "at fantastically low rates." He says, "Not a week, nor scarcely a day, goes by but what our firm is approached by some worthy small enterprise seeking from $\$ 50,000$ to $\$ 100,000$ of capital to develop or expand.a sound small business or to start a promising new venture. But this sort of money is not available in New York." He goes on to appraise the various remedies that have been offered and finds them all wanting. As to the A.B.A. proposal for credit pools

\footnotetext{
- Fed. Res. Bank of N. Y., Monthly Review (Dec. I, I944) 9 I.

${ }^{5}$ F. Eberstadt, Speech before the 27th Annual Convention of the National Association of Securities Commissioners, St. Louis, Dec. I2, I944.
} 
he makes this comment: "This may, to a limited extent, furnish credit facilities but unless it is done very generally, which does not presently seem to be likely, its effects will not be substantial or widespread." He is, of course, intimately acquainted with the mentality of investors who "have been keenly security-conscious and are timid about taking risks" and knows, therefore, that for small securities issues, "there is no national market." Therefore, he has put forward in modest and tentative vein his own proposal for the formation of community investment companies or pools of capital, with perhaps a government contribution in the form of the purchase of preferred stocks of such companies.

Mr. Eberstadt does not share the concern of many of his fellow bankers at the prospect of government financial aid to small business. On the other hand, he expresses his conviction "that unless we find such adequate solution for these problems we cannot achieve that measure of post-war employment and production which is necessary for our own national welfare and without which I fear there can be neither peace nor prosperity in the rest of the world."

It must be admitted that Mr. Eberstadt has put his finger on the sore spot as few others have done. He has not minimized the problem nor attempted to isolate it from its proper context. But while admiring his comprehension of the problem we may still share his own doubts as to the effectiveness of the measures which he suggests. For one thing, it is regrettable that Mr. Eberstadt has not included reduction in the costs of capital as an objective of his program. And further, if small business financing is the national problem which he envisages, one may well question the wisdom of disposing of it by turning it over to the vagaries of local communities, states, cities, towns or villages. What assurance would this give that the needs of any one community would be met, or that the neediest communities from point of view of business capital would bring forth the most liberal supplies? Indeed a realistic prediction would seem to reach just the opposite conclusion. If the small business financing problem is accepted as a widespread and national one it can be effectively and equitably approached only by national measures. Certainly the records of the numerous community industrial financing plans which have been operating for many years provide no reason to expect a substantial contribution from such sources.

\section{II}

There are certain assumptions that are common to almost all discussions of the small business financing problem. Among these are the following:

I. That large corporations have been increasing their share of the total production and distribution of goods and services.

2. That small businesses are generally undercapitalized.

3. That small business has suffered during the war years.

4. That there is insufficient credit available to small business to fill their needs.

There has recently been developed some rather interesting research bearing on each one of these points. The results of this research raise substantial questions as to the validity of these assumptions. 
Taking them in turn, as to the first assumption, the available data which is quite reliable does not support the general feeling that small business is being forced to the wall. One of the prime examples in support of this assumption has been that of retail trade in which the chain stores and mail order houses are supposed to have made large incursions into the field of distribution. The following figures, however, may clarify what the actual trend has been:

Sales of Chatn Stores and Mail Order Houses as a Percentage of Total Retail Sales

$\begin{array}{lllll}2929 & 1933 & 1939 & 1941 & 1943 \\ 21.4 & 26.9 & 22.9 & 22.5 & 23.2\end{array}$

While there was apparently a trend toward an increased ratio of sales by the larger units during depression years, the evidence of later trends raises considerable doubt as to whether this was, in fact, indicative of a secular movement. Similar data indicate that in the manufacturing and wholesale trades, small business has at least held its own in relation to total volume of goods produced and sold during the past five years. While these data are inconclusive and need to be supplemented, they do seem to raise questions as to the assumed trend and as to certain predictions based upon this assumption relative to the eventual extinction of small business as an important element of American economic activity.

As to the second assumption, that small business is generally undercapitalized: it is well known that for at least a generation small companies have either by choice or by necessity operated on a far smaller ratio of current assets to liabilities than large corporations. There is no compelling evidence of a narrowing trend in this ratio during the past decades. In fact, there is some reason to believe that the working capital of small businesses has been increased during the five war years even more substantially than that of large corporations. The Securities and Exchange Commission has published quarterly estimates of the working capital of all American corporations broken down into its components. These reports have shown a tremendous increase in corporate working capital during the five years, 1939 through 1944, to a total figure which is unprecedented in our history. ${ }^{\circ}$ Furthermore, this huge accretion of capital has been in highly liquid forms particularly cash, bank deposits and short term United States government securities. The distribution of this working capital seems to be pretty uniform throughout the economy and while varying between different industry groups it seems that the smaller sized corporations have enjoyed a substantially larger increase in their working capital position than have the larger. While the data for small companies are not as complete as would be desired, the evidence which has been accumulated from all available sources uniformly points to this conclusion. Naturally this does not mean to imply that there are no small enterprises with inadequate working capital in relation to post-war needs. But it does seem to raise the question as to whether such a condition is widespread or general.

'See S.E.C., Release No. 747, Feb. 21, 1945, Statistical Series, and subsequent releases in this series, 
As to the third assumption, much has been heard in recent discussions of the numerous war casualties among small business. There is no question but that some small concerns have been forced to close down because of the war mobilization and the draft. But this does not justify the inference that small business in total has suffered during the war. In fact, recent research by the staff of the Board of Governors of the Federal Reserve System would seem to indicate that small business as a whole has prospered very handsomely during the war. ${ }^{7}$ In this field also it would be helpful to have a larger coverage than has been available to date but here also it is notable that the only information which is presently available belies the common assumption as to the wartime experience of small business.

The final assumption above mentioned is to the effect that there is insufficient credit available to small business to provide its needs for commercial loans. Stated in this manner, and it is in this manner that the assumption is invariably stated, it is quite obviously a false postulate. The commercial banks have never been so stocked with deposits and probably have never before been so eager to do business on a profitable basis. This means that there is ample potential credit for all business. But the trouble is that this potential supply must be made to flow and in order to bring this about certain conditions have to be fulfilled. Firstly, the commercial banks would have to revise their estimates of what constitutes a reasonable risk. And secondly, the commercial banks must revise their asking price for credit from small business. This they have given no indication of their willingness to do. The factor of cost has been uniformly and completely ignored in the plans proposed by the bankers for small business financing. With a price of $6,7,8$ percent or higher for short and medium term loans to small and new ventures compared with a rate of $I$ to $2 \frac{1}{2}$ percent for large corporations it is no wonder that there appears to be a scarcity of funds available for short term loans to small enterprises. This then, is the heart of the problem, that is, how to bring down the cost of funds, and not how to increase the available funds which are already fantastic in amount.

This disparity between the cost of funds to large versus small business is not confined to the field of short term credit nor does the responsibility rest entirely upon the commercial banks. The cost of long term loans in the public investment markets through the instrumentality of the investment bankers is practically prohibitive for the small businessman so that only "seasoned corporations" can obtain loans in the public capital markets. Some funds have been obtained by smaller corporations by the sale of equity securities. But the cost of these funds also has been exorbitant particularly in contrast to the financing costs of large corporations. In a recent report, ${ }^{8}$ the Securities and Exchange Commission set forth the cost of flotation of equity securities for small issuers. This shows that on the average small corporations paid over 20 percent to obtain capital in the public investment

${ }^{7}$ Dirks, Wartime Earnings of Small Business (Jan. 1945) FED. Res. Bull. I6-26.

${ }^{8}$ See S.E.C., Release No. 744, Oct. 22, r944, Statistical Series. 
markets. Out of this 20 percent about $19 \frac{1}{2}$ percent was retained by the investment bankers or underwriters for the preparation and sale of these issues. This compares with a cost of 3 percent on sales of large equity securities, that is those aggregating more than $\$ 5$ million. It is interesting to note that the cost of registration with the Securities \& Exchange Commission for small as well as large issues is about the same proportionately and amounts to less than I percent of the value of the issue, and that issues of less than $\$ 100,000$ are totally exempt from registration requirements.

One of the most fertile sources of small business funds in recent years has been the accounts finance companies. The growth of business of these companies has been sometimes referred to as one of the outstanding economic phenomena of our times. During the I920's the increase in the volume of the business of finance companies was certainly phenomenal and while this volume fell off somewhat during the early $30^{\circ}$ 's it had by 1937 reached new high levels. While the finance companies have extended their lines of credit to certain small business ventures to which commercial banks have been inaccessible it is primarily the cost of the money obtained through these companies that renders their services to the small business financing problem of very doubtful value. Because of the variety of charges levied by the finance companies on borrowers it is difficult to ascertain accurately what the cost of the total accommodations actually amounts to. It is, however, estimated that the over-all cost of such funds never is below to percent, more commonly runs from I4 to 20 percent and sometimes as high as 35 to 40 percent of the value of the loans. While credit seems to be available from this source it is quite apparent that we cannot expect to find here a solution to the cost of credit problem.

In addition to these private sources of credit there are several government agencies which have for some years been vested with authority to relieve the small business financing situation and have been provided with rather substantial funds for this purpose. By amendment of the Federal Reserve Act in 1934, the member banks of the Federal Reserve System were authorized to extend credit to small business. Funds provided for this purpose aggregate $\$ 280$ million. The Reconstruction Finance Corporation was established in 1933 and among its functions was the provision of relief to small business. No limit was set on the amount of its funds to be employed for this purpose. The record clearly demonstrates that neither R.F.C. nor the Federal Reserve Banks have ever employed these funds to anything approaching the full extent authorized by law.

For example, in the five-year period from 1934 to June 1939 , only $\$ 180$ million of the funds available to the Federal Reserve Banks had been actually used by them for small business loans. But even more revealing is the fact that at no time have their outstanding loans from these funds amounted to more than $\$ 32$ million. In other words, less than 12 percent of the funds available to the Federal Reserve Banks has been used by them to help small business. As to the R.F.C. record, no information is available as to the size of the firms to which their loans have been 
made, but the size of their loans gives a clear indication that their funds have not been used to an appreciable extent for small business financing. Between 1932 and I939 less than 4 percent of the $\$ 450$ million in authorized R.F.C. loans were in amounts of less than $\$ 10,000$ and only 30 percent in amounts under $\$ 100,000$.

The addition of the Smaller War Plants Corporation to a list of government institutions with funds available for small business, while justifiable would seem to need certain reservations at this time. For one reason, because S.W.P.C. is a temporary agency devised for the convenience of small war contractors and to promote war production and mobilization among this limited group of small businesses as well as to be of assistance in the reconversion and demobilization period. Whether S.W.P.C. will, in the future, make a contribution to the general and long term financing of small business would involve a prediction which it seems unwarranted to make at this time on the basis of the known factors.

As to R.F.C. and Federal Reserve Bank operations in the field of small business, it is notable that they have had absolutely no effect upon the high cost of borrowing. Indeed during the period of operation of these public financing institutions, that is from 1934 to date, rates on loans to and spreads on offerings of securities for small business have either not receded at all, or have stiffened and increased. And this has taken place during a period of consistantly easy money rates, when financing of large corporations has been in volume at rates of $x$ to 3 percent depending upon length of maturities, and call money a glut on the market at I percent.

III

One of the most fertile areas of confused thinking in the discussions of small business covers the controversy over equity versus debt financing. Many speakers and writers on the subject, both in government and in private banking have expressed a decided preference for "equity financing" over long term loans as a medium for providing capital to small business. This preference for "equity financing" probably stems in large part from two sources. One source is a kind of vague, but generally accepted, feeling that a large volume of private debt is a drag on the economy, and augments business depressions. This type of thinking was particularly common during the I930's when everyone was looking about for a cause and a cure for the depression. Debt was pounced upon as a cause, and the replacement of lending by equity investment looked like an attractive and ready-made cure.

The second major source of the preference for equity versus debt financing was the integrating and capital simplification program of the Securities \& Exchange Commission undertaken pursuant to its administration of the Public Utilities Holding Company Act of r935. After it took jurisdiction of the country's vast and complex network of holding and subholding companies, the S.E.C. was justifiably disturbed by the top-heavy debt structures of many of these companies. The realization of the effects of this typical capital structure on the control of operating units, on the interests of public investors and on the quality of service and level of rates was something of a shock to the S.E.C. It was quite natural and logical 
that it should have proceeded, as it did, to simplify utility holding companies' capital structures by paring down debt and raising equity capital to a more important ratio to the total. And in this process the S.E.C. issued quite a few opinions in which it gave clear expression to its favor for the replacement of debt by equity capital and the expansion by means of stock rather than bond issues. These opinions, of course, were addressed to the field of public utilities, that is to companies engaged in the generation, transmission or distribution of electric energy or gas power, and more particularly to individual companies within this area. It is largely from this source that can be traced the recommendation for "equity capital" that is found in the T.N.E.C. Monograph on the Problems of Small Business ${ }^{9}$ and has been repeated in some recent discussions of these problems.

Two points may be noted relative to these sources of the equity financing preference: first that as to the contribution of debt financing to business depression, maturer thought has raised considerable doubts. If the presence of a large volume of private debt was a contributing factor at all, it was obviously an infintesimal one relative to the actually creative causes. In fact, some economists still hold that the presence of debt in the 1930's might have considerably mitigated or shortened the extent and duration of the depression if economic forces had been permitted to operate freely. While this kind of logic must perforce remain in the sphere of the hypothetical there seems to be some plausibility to this argument. Certainly it would seem like treating the symptoms rather than the disease to expect to stem or avoid a depression by converting debt into equity or by increasing corporate common stock capitalizations during years of prosperity while holding debt in check. We have good reason to hope for the alleviation of the severity of business cycles by any one of a number of realistic programs that have been or will be submitted for the consideration of Congress in the not too distant future. Surely to the extent that such measures are adopted and successfully administered the choice between equity and debt financing based on long term economic effects becomes for all practical purposes a moot question.

And second, that equity financing may be recommended for public utility holding and operating companies for a number of reasons, none of which apply to the provision of capital for small private concerns or to new ventures. In fact, one finds scant justification among its proponents for the translation of the equity capital preference from its application to the giant capital structures of the public utility industry to the modest needs of the corner grocer and the local manufacturer.

In spite of the questionable importance of the choice betwen equity and debt capital for small business, it may be useful to examine the meaning of these terms. The ambiguity with which the term "equity capital" is frequently employed, and the variety of meanings that might be assigned it are further illustrative of the confusion that has crept into the discussions of this issue.

All too frequently the term equity capital has been employed as including pre-

- T.N.E.C., op. cit. supra note $\mathrm{I}$, at 237. 
ferred stock. For example, in the T.N.E.C. Monograph No. I7, we find this statement: "Equity capital can be provided through government or private agencies purchasing preferred stock of small businesses."10 And in a recent book ${ }^{11}$ which purports to be a thorough analysis of the small business problem, the author after constant reiteration on the advisability of promoting equity financing comes forth with the proposal that a new financing corporation should "have authority to make loans and purchase preferred stock-to aid in the financing of small and medium sized business." This equating of equity capital with preferred stock is of questionable soundness resulting either from an unintentional confusion of financial terms, or from an implicit attempt to compromise the entire question of debt versus equity financing. Equity capital really means capital invested in a business and subject to no conditions other than the full risks of the enterprise and to no rewards other than a share in the net profits of the venture. In other words, there is no fixed or guaranteed return for the provider of equity capital, that is, he is not a preferred stockholder.

The purest form of equity capital is, of course, common stock. This form of capital stands in sharpest contrast with that form of debt capital which is represented by the mortgage bond. These are the extremes of equity and debt capital respectively. Between these extremes there is a gradation of securities which can be classified in either category, equity or debt, almost at the discretion of the user of the terms or the legislator. For example, in the Securities Exchange Act of I934 "equity security" is defined ${ }^{12}$ as "any stock or similar security or any security convertible-into such a security, or carrying any warrant or right to subscribe to or purchase such a security: or any such warrant or right: or any other security which the Commission shall deem to be of similar nature and consider necessary or appropriate, by such rules and regulations as it may prescribe in the public interest or for the protection of investors, to treat as an equity security." In this limbo of definition one will find among others preferred stocks convertible into common, non-cumulative preferred stocks, participating preferred stocks and even cumulative preferred stocks. One will also find in this classification of equity securities certain types of bonds such as those convertible into common stocks or those carrying warrants or rights to purchase common stock.

At the other end of the scale long term debt in addition to first mortgage bonds, would include general and consolidated mortgage bonds, collateral bonds of various types, debenture bonds and unsecured notes. When we inspect these two classes of securities which comprise on the one hand equity capital and on the other hand debt capital, we find that many of their essential characteristics merge and leave little or no distinction especially for the purpose of our discussion. If equity and debt financing are taken to mean any or all of the above variety of securities, any advantages that might have been claimed for the straight common stock over

${ }^{10} \mathrm{Ibid}$.

11 Weissman, Small Business and Venture Capital (i945) 90.

${ }^{12} 48$ Star. 882 (I934), I5 U. S. C. (I940 ed.) $\$ 78 \mathrm{c}(\mathrm{a})$ (II). 
the first mortgage bond have completely vanished. For example, is there any essential or practical difference between the cumulative preferrd stock and the debenture bond; or between the convertible preferred stock and the convertible bond from the point of view of either the business proprietor or the investor?

From the point of view of the business proprietor, one of the principal advantages claimed for equity financing over borrowing is that in the event of failure to earn sufficient to pay dividends or interest he is not subject to foreclosure or equivalent measures. But a preferred stock is scarcely distinguishable from a debenture bond in this respect if the dividends are cumulative. The only benefit to the business proprietor in having preferred stock rather than bonds outstanding is that no obligation to repay is involved in the former case. For this advantage, however, the owner often pays dearly either in the form of a higher rate for the money, or by ceding certain voting and management rights or by both. These costs may often not be worth the advantages received. In fact, there may be advantages to the maturity of debt provision over non-maturity of preferred stock, paradoxical as this may seem. As to interest, as well as dividends, common or preferred, there are payments as a general rule only when there are earnings sufficient to make them. This is certain as to small business at any rate. Unpaid preferred dividends accrue just as does unpaid bond interest. But at the time of maturity if the proprietor is not in position to pay off his debt or to refund it, he has at least the opportunity to make some kind of a settlement or obtain a postponement from his creditors. He is often able as a result to reduce his capital charges and his outstanding capital by a debt composition. On any kind of debt other than a pledge of property, a mortgage bond, the creditor has little recourse except some kind of a settlement. There is nothing shameful in this procedure and our laws have progressively facilitated just such settlements. In so doing they have constantly reduced the incidence of liquidation or reorganization which heretofore were the only courses of action open to the company in default.

Thus, the proprietor in time of individual stress or of general depression can now free himself from a part of his cost of capital if it is in the form of debt, and by so doing put himself in a financial condition which might make him eligible for new financing. Under similar circumstances, it is far from clear that a business having only preferred equity capital is any better situated.

From the point of view of investors any imputed preference for preferred stocks over bonds would have been considerably mitigated by recent amendments to the securities laws of various states and recent court decisions respecting them. One of the effects of these laws and judicial opinions is further to reduce any substantial difference between bondholders and preferred stockholders. For example, the constitutionality of an amendment to the New York State Stock Corporation Law which facilitates the reclassification of corporate preferred stock and the elimination of accrued and unpaid dividends has recently been upheld. ${ }^{13}$

\footnotetext{
${ }^{13}$ McNulty v. W. \& J. Sloane, — Misc. —, - - N. Y. S. (2d) —— (1945), I Prentice.Hall Corp. Serv. ף 20,966 .
} 
The above assimilation of the preferred stock to the debenture bond relates to those in which the dividend is cumulative. There is nothing to be gained by introducing into this discussion the virtues of non-cumulative preferred stocks. This class of securities is for all intents and purposes only a common stock with limited divends. It is frequently referred to as a fake common stock, or a common stock in disguise.

Common stock financing has certain special advantages for the business proprietor as well as certain drawbacks, while for the investor in small and privately held business, common stocks are nothing but a headache. As to the business owner common stock has the obvious advantage of not entailing fixed capital charges. If the owner of the business continues to exercise voting control he can also retain complete managerial discretion including the declaration of dividends or the retention of profits much as he pleases. He can even go farther than this and, in substantial degree, affect the profit showing of the business by salary adjustments, including his own, or by paying out bonuses or setting up profit sharing plans for himself and his employees.

But if the owner of the business has to cede voting control in order to obtain equity capital there is a far different story. Then his business is no longer his own, and he is more at the mercy of outsiders than is the proprietor of a business having long term debt. There are probably but few small business proprietors who would be willing to become minority holders of the voting stock of their own businesses in order to obtain capital, short of a point of desperation.

Many of the factors which make common stock financing attractive to the proprietors are the very ones that make common stocks of small businesses unattractive to investors. As a minority stockholder the public investor is entirely dependent upon the generosity or caprice of the owner of the business for his income even in good times. And investors' experiences in such ventures have shown them that owners are very reluctant to share their profits in the form of dividend payments and far more frequently prefer either to hold or reinvest profits or to raise their own and their associates' remunerations. Furthermore, many small business managements with common stock held outside the family or social circle consistently withhold from such stockholders any information as to the affairs of the business, refuse to answer their inquiries or to render balance sheet and profit and loss information. It may well be that this lack of accessible information is an important contributing cause of the investment public's antipathy to the securities of small business, and one of the real reasons why these securities are not marketable at all. This results in part from the fact that small issues of securities are exempt from registration under the Securities Act of 1933 so that the data which investors look for today when considering a new issue are not required of small companies. Paradoxical as this may seem, it would appear that this exemption from registration far from being an advantage to small companies is actually an impediment to the public's reception of their securities issues. 
It has sometimes been suggested that equity capital financing should be promoted by a quasi-public or government institution, either by direct investment or by guarantee provisions. If these proposals envisage financing by preferred stocks only it is submitted in view of the above discussion that they carry no advantage to the small entrepreneur over debenture bond financing. On the other hand such proposals raise serious questions as to voting rights, management, and possible control of private business by government which, at this stage of economic and social thinking in the United States, it would seem desirable to avoid. While common stock financing has certain advantages, it must be evident that proposals for government assistance to small business in this form, are confronted by this same set of embarrassing questions as to rights and powers. In fact, by injecting the equity financing proposal into programs of direct or indirect government assistance to small business it seems that the protagonist of the little businessman may have done his cause more of a disservice than a service. The implications of such proposals are invariably seized upon in public debate as involving a socialistic strain, and the case for common stock participation in small ventures by public bodies is not good enough to offset such criticism. As a result, programs of government aid which might otherwise have received sympathetic consideration have become bogged down in discussions on free enterprise versus totalitarianism.

In view of these political circumstances and of the substantial doubts as to the needs or merits of equity financing to small business, its omission would certainly seem to be no derogation from programs involving government participation. Surely much could be done through government action by means of loan financing and probably all of the apparent demand for capital funds could effectively be supplied in the form of debentures or notes, particularly if the following conditions are accepted: I. Rates of interest substantially below current levels, commensurate with the borrowing rate for large corporations; 2. long term maturity dates and flexible amortization arrangements; and 3 . liberal indentures and refunding provisions. Under such conditions bond financing would seem to be better adapted to small companies than stock, would avoid the conflicts of interest which bother the proprietor on the one hand and the investor on the other, and is the only politically feasible mode of financing by quasi-public and government institutions.

\section{IV}

On April 29, 1938, President Roosevelt, in a message to Congress on the concentration of economic power, referring to the position of small business said: "The heavy hand of integrated financial and management control lies upon large and strategic areas of American industry." Here is a comprehensive statement of the financial problems of small business which unfortunately seems to have been overlooked in much of the recent discussions of the subject. The problem set forth by President Roosevelt is the one which results from the dependence of large segments of American industry and commerce, including small business, upon the predilec- 
tions of commercial and investment bankers. The little man's difficulty in obtaining funds for current operations as well as for capital purposes, and the disparity in the cost of such funds as between small and large concerns is one of the direct results of this dependence.

For at least a generation, small companies have found it practically impossible to obtain funds for expansion in the public capital markets. To a somewhat lesser extent new business ventures have also found it difficult to get capital to start with. However, there was always some speculative and promotional capital for attractive new enterprises at least until the collapse of the investment markets in rg29. Since then new ventures have met with about the same resistance from investors and the same stiff banking charges for such accommodations as they have been able to eke out as have small and established enterprises. In fact, a working definition of small business which would also cover new business might be based upon this very situation. Thus, "small business" could be defined for purposes of discussion as any business established or projected which either cannot obtain capital funds at all or can obtain them only at exorbitant rates in the capital markets. A similar definitory formula could be based on differential rates for commercial loans as between large, and small or new business. This kind of definition avoids the necessity of a quantitative standard based on value of assets, volume of sales or number of employees each of which presents difficulties of application. Mr. Eberstadt has said in the speech quoted above, that investment bankers are actually averse to financing issues of less than $\$ 100,000$ and indifferent to those involving less than $\$ 1,000,000$. This is not a new attitude or even one predicated on any sad experience of the depression. For years the principal financial community has been closed to the man looking for just a small amount of capital to start or to expand his own business. Wall Street bankers and their securities markets had other fish to fry in the I920's, fried very little or no fish in the I930's and are looking for the big fish in the late r940's and 50's.

While this attitude of the bankers should not be set down as mere prejudice, it is, nevertheless, not justifiable by the profit experiences in small business financing. Actually the bankers' atittude derives from the disinclination of investors to purchase the securities of small companies. One of the reasons for this disinclination is that these securities are not liquid, they cannot be bought and sold readily, they do not enjoy a "good market." Another reason is they are too risky and don't return enough more in the form of dividends or interest than the seasoned issues to justify the added gamble. It is, therefore, highly questionable whether small business issues will be any more marketable after the war than they were before, in spite of the enormous accumulation of liquid public savings which are eagerly seeking investment outlets.

Of course present tax rates have a bearing upon this apparent public apathy toward risks and profits. Not so much the business or corporate taxes, as personal surtax rates and to a far lesser extent capital gains taxes have bred some indifference 
to profit potentialities, so much of which if realized are recoverable by the government. But high taxes for the foreseeable future is a postulate which can hardly be questioned. There will no doubt be some shifts in the tax burden as between business directly and the individual stockholder. Some alleviation in the tax burden throughout from war-time rates is of course predictable. But it would be overoptimistic to expect that tax relief alone could provide any substantial change in the basic psychological determinants, particularly as these attitudes of investors antedate the war and were established when tax rates were considerably lower than they will probably be for many years to come. Mr. Randolph Paul, former General Counsel of the Treasury Department in charge of fiscal matters, recently expressed the opinion that tax alleviation alone should not be relied upon to solve the financial dilemmas of established small enterprises or to find funds for launching new ones. ${ }^{14}$ It is even more difficult to concede that the cost of credit or capital to small business would be measurably affected by amendment of the rates of tax on business profits or on individual incomes.

One answer to the financial dilemma of the small enterpriser might be looked for through the commercial banking system were he able to obtain short term credit there readily and reasonably. It is only fair to say that this relief, however, would not solve the problem of new enterprise or of expanding business because what these should have are not commercial loans of short or medium duration but long term funds. Unlike the investment banker, the commercial bank is apparently receptive to the loan applications of small concerns and is ready to fill them provided the prospect is a good business risk. The commercial banks have enormous funds at their disposal in the form of deposits at the highest level in the history of the country. In a sense this makes the argument for more funds to finance small business look somewhat ridiculous. In fact, this situation prompted the Federal Deposit Insurance Corporation in its annual report ${ }^{15}$ for the year ended December 3I, I943, to decry the "doubts concerning the ability of banks and other private financial institutions to finance business enterprise." The "ability" of the banks has, of course, never been in question. The banking system had the ability in terms of cash and deposits all through the depression years. It is the willingness of the banks to do the job that was then, and still remains, the real question.

Quite obviously the rub in the short term credit mechanism for small business is not so much the availability of funds but rather the cost of credit. During the past ten years there has been a disparity of from 3 to 6 percent between the lending rate of commercial banks to large business and the rate for similar term loans to small business. Large business can borrow short and medium term funds at $\mathrm{I}$ or 2 percent. It is almost impossible for a small businessman, no matter how good his credit status, to obtain funds below 5 percent and most small loans probably carry a rate of 6,7 or 8 percent and so on up. What statistical research has been

\footnotetext{
${ }^{14}$ Specch on "The Future of Small Business Taxation," before the New York Employing Printers Association, Hotel Commodore, New York City, Feb. 26, 1945.

${ }^{15}$ Federat Deposit Insurance Corp., Annual Report (Dec. 31, 1943) 12.
} 
done on the profit performance of small business as compared with large, on the rate of failures and so on does not provide an adequate economic justification for such discrepant rates.

Back in the days of the T.N.E.C. hearings, Mr. Adolph Berle, then Assistant Secretary of State, appeared before the Committee and discussed the question of commercial bank rates. In cogent terms he disposed of the generally accepted presumption that rates of interest were a mathematical function either of risks or costs. ${ }^{16}$ He made the point that commercial bank rates were determined almost entirely by what the bankers considered to be their optimum rate of profit on a given set of transactions. The cost of banking funds to private enterprise, therefore, depends upon what profit per share the commercial banks feel they should be able to report to their stockholders. Or otherwise stated, the evaluation of what constitutes a "reasonable risk" on a loan application is actually determined by a standard or minimum rate of profit for the lending institution.

In the light of this analysis our problem of financing small business might be considerably elucidated by an examination of the bankers' concept of optimum profit which in turn affects the determination of "reasonable risk," a highly important consideration in the field of commercial banking. Of interest by way of illustration is the following statement made five or six years ago by $\mathrm{Mr}$. E. E. Brown, President of the First National Bank of Chicago, in the course of the Senate Committee hearings on the Mead Bill: "Virtually no small or medium sized business which is entitled to credit either for a short or a long time and which can give reasonable assurances of repayment, fails to get it." It is necessary to read between the lines of this statement, and to interpret such ambiguous phrases as "entitled to credit" and "reasonable assurances of repayment" in order to understand just where Mr. Brown stands. His formulation of the bankers' position is not very different from that just recently taken by the American Bankers Association in announcing the formation of credit groups to increase the availability of bank credit to small business enterprise. It states that the purpose for the formation of these groups is "to assure that every competent man, firm or corporation that needs bank credit for some constructive purpose will get it."17 The judgment as to who is a "competent man" and what is a "constructive purpose" will of course continue to be made by the banker and such judgment, we may be sure, will be predicated upon the same concept of reasonable risk, i.e., adequate profit per loan. And here also as in $\mathrm{Mr}$. Brown's statement, is not a word as to a prospective reduction in the cost of credit to small business.

It seems quite evident that the dilemma presented by this set of psychological determinants of the financial problem has not yet been met either by the bankers, or by government financial agencies, nor has it been faced by any of the solutions proposed to date. Why have government and government owned financial agen-

${ }^{10}$ Hearings before the Temporary National Economic Committee, 76th Cong., xst Sess, Part 9 (1939) 3820-3821.

${ }^{17}$ Fed. Res. Bank of N. Y., Monthly Review (Dec. I, r944) 9r. 
cies, such as R.F.C. and the Federal Reserve Banks, failed either in the provision of needed funds to small business or in bringing down the cost of such accommodations? The answer seems to be that they also have used the "reasonable risk" yardstick as their lending criterion. Apparently the liberalization of this formula has not been obtained by transferring the banker from the private to the public payrolls, or in other words by continuing or setting up autonomous government financial institutions.

The same kind of inhibition may reasonably be expected to attend the various proposals for government participation in or underwriting of private banking in the field of small business. It is submitted that no plan for the alleviation of the small business financing problem has much of a chance of success which would retain the formulation of credit policy by the bankers, without any assurance that they will apply a radically regenerated concept of "reasonable risk." But none of the plans for government guarantees can give this assurance. In fact, there is reason to suspect that the cost of funds might be increased under such plans because of the added guarantee fees and administrative expenses of the public agency. Such arrangements might even become an underwriting by the government of the bankers' rate of interest and profit differentials, as well as a guarantee against risks or losses.

Most of the proposals to enlist government assistance in the financing of small business favor a system of government guarantees of private financing or the assumption by government of private risks rather than direct lending or investment by the government. Proponents of these plans apparently assume that a banker would be more liberal and less cautious in providing accommodations with a government guarantee to absorb a good share of his potential losses. But this assumption belies the acquaintance of its holders with banking psychology. No bank is going to voluntarily put itself in a position of having to come to the government from time to time to be bailed out of bad loans. Almost any given bank official confronted with a loan application which by his standards is too risky just couldn't say "yes" although he has assurance that the government will help him out in case of loss. The trouble is that if he should make enough loans that turn out to be sour, even though the bank may not be out of pocket, yet a record has been made which impugns his judgment and may damage his reputation in the financial community. A vice-president of a bank who had approved a number of loans which required the bank to go to the government for help would have very little chance of becoming president of that or any other bank.

On the other hand, the Federal Housing Agency is sometimes offered as an illustration of successful private financing under government guarantees. But to urge this analogy is to overlook certain fundamental differences between the financing of homes by mortgage companies on the one hand and of businesses by banks or investors on the other. A house is a tangible asset subject to fairly accurate appraisal of value. A business is a bundle of potentialities. A house owner who meets financing charges on his property is only paying rent. A mortgage debt 
may be quite appropriate in the real estate field, but in the field of business it is credit on a note, or on a debenture bond with a liberal indenture that is wanted. Businessmen are justifiably reluctant to pledge fixed assets for loans in the light of their past experience. Furthermore, there is far less reason to expect bankers to respond to government guarantees to anything like the favorable degree of response received from the real estate mortgage companies.

But even should a commercial bank pool, with or without government participation, turn out contrary to these expectations and operate successfully, only a part, and perhaps the least important part, of the small business financing problem would have been taken care of. The spokesmen for small business have most vehemently appealed not for short or medium term loans but for long term loans to be used as capital for the expansion of their businesses. Funds for such purposes cannot be supplied by the commercial banks but would normally be sought in the public capital markets. In recent months several suggestions have come from the investment banking community to unfreeze the capital markets for small issues. These proposals are similar to the plans of the commercial bankers to the extent that their essential feature involves the establishment of regional pools of capital or of regional investment trusts. Apparently it is felt that underwriters in consort would be willing to undertake financial risks which individually they have eschewed; also that investment banking or underwriting has been too exclusively centered in the Wall Street area and that a geographic distribution would encourage a revival of independent regional financing of local enterprises. Investment bankers' plans are invariably addressed to the problem of increasing the amount of investment capital available to small business, but have given no attention whatsoever to the possibility of decreasing the cost of obtaining such funds. If, however, either equity or loan capital to small business continues to be conditioned upon a fee of 20 percent to the underwriters there would appear to be but small relief in the offering of added accommodations.

One of the reasons for the investment banker's refusal to do business with the small enterprise is his knowledge that his client, the private investor, would not take up the offerings of such issues. Therefore the investment banker would have his own capital tied up in these investments and notwithstanding the general impression of the wealth of the banking industry, its capital is, in fact, not of such proportions as to allow of many such long-term commitments. The American investment banker, unlike his British cousin, is more of a salesman than an underwriter. Our investment bankers underwrite only those issues which they have reasonable assurance of being able to sell within a very short time period measured, in terms of hours preferably and of days at the most. "Sticky issues," that is those which have to be shopped around in order to be disposed of, are avoided like the plague. Small business issues are perforce "sticky." It is not clear how this condition would be altered by the proposal to establish investment banking pools or trusts as a substitute for individual firms. 
There is substantial question as to whether regional investment bankers, that is those outside of the largest financial communities, would be attracted to local ventures. Time was when some community enterprises could have gone to the local investment bankers for capital, particularly if they were friends in the social sense. But in those days the local banker had very little other business to keep him going. Times have changed, however, and today the local investment bankers no longer underwrite local issues, largely because he has other sources of business which are equally or more remunerative and considerably less risky.

The interest of the local bankers today is practically absorbed in two types of transaction. First, in respect of new issues as members of selling groups organized by the large underwriting firm in the large financial community. And second, as dealers in the over-the-counter markets. These fields of activity provide the regional financier with sources of revenue at least as rewarding and considerably less risky than the underwriting of small issues for local enterprises.

Much has been spoken and written in favor of a pool of funds to be subscribed to by the local citizenry and to be loaned to or invested in new and expanding enterprises within the community. This is the kind of a program which has considerable appeal particularly to those with a nostalgia for the old forms of democratic organization, like the cracker barrel group. But is it realistic to expect businessmen to promote the establishment and renovation of their competitors by advancing funds which these unfortunate competitors haven't been able to obtain even from the local bank? Would a directorate which included the leading community apothecary, for example, be likely to finance an ambitious new druggist? The amount of log-rolling which would undoubtedly emerge in such a community arrangement would probably sink the whole project in a very short time.

Community financing plans have been in operation in various parts of the United States for the better part of the twentieth century. Many of these plans have attractive features, and are made particularly so by pamphlets and other descriptive literature prepared for distribution. But it is rather sad to report that the record of their accomplishment hardly fulfills the bright promise of their creators. The United States Chamber of Commerce recently compiled a collection of reports on community industrial financing plans. ${ }^{18}$ Review of this compilation makes it plain that this kind of approach is not the answer to our problem of financing small business. In the years that these plans have been in existence they have obviously not even scratched the surface of the problem. Even the most touted of these plans can show a record of actual achievement which is small in relation to the size of the community. The amount of financing done by all these plans over the course of their period of operation can have made no measurable contribution to the total economy. Perhaps the same ghosts of "reasonable risk" which haunt the private and public financial institutions are also found in the community councils.

\footnotetext{
${ }^{28}$ Chamber of Commerce of the United States, Community Industrial Financing Plans (mimeographed, undated but actually published in 1945).
} 
The most recent revival of the community financing formula has been put forward by the Investment Bankers Association. In April of this year it submitted to the Senate Small Business Committee a plan ${ }^{19}$ which is a generalized community finance organization not very different, from that suggested by Mr. Eberstadt except that the government contribution would be made in the form of loans to the community groups by the Federal Reserve Banks. In fact, the Federal Reserve Banks would be obligated generally to advance to these local groups three times as much as the community had contributed as capital, provided the Board of Governors of the Federal Reserve System had granted charters to these groups. Thus, while it is intended that the operations of the groups should be vested in the communities, it would seem that the Federal Reserve System could exercise quite a decisive influence, not only in the actual granting of the privilege to do business, but also in the selection of managements and directorates upon which policy after all so closely depends. In this connection it is interesting to note that the I.B.A. plan seems to contemplate a board of directors made up entirely of businessmen and bankers with no representation being reserved for representatives of local labor or agricultural interests.

No new principles are involved in this proposal of the I.B.A. and the same set of questions presented above are pertinent to it. Apparently it is conceded that the financing of small business is to much of a job for the investment banking industry under its present unorganized but highly centralized set up. Therefore, organization and decentralization are proposed as solutions, plus the not inconsiderable contribution by government of three times the private subscription, and the further protection to the local capital afforded by the required purchase by the borrowers of a junior common stock.

All of these proposed formal amendments to the present investment banking system, as well as those proposed for commercial banks continue to leave the basic questions unanswered. For example, what indication is contained in the I.B.A. plan that a liberalized standard will be applied as to the loans and investments of the proposed groups? The requirement that each local Federal Reserve Bank "would investigate and report to the board the qualifications of the board of directors and management of the proposed company" would seem to insure the employment in these capacities of the very same personnel who now establish loan and investment standards and requirements. But even should the management be more generous with the funds of the group (composed, that is, one quarter of private and three quarters of public contributions) than they have been with their own as bankers, what can be looked for in the way of cost reduction? At a continued cost of 20 percent for new equity capital it could hardly be said that the financial vicissitudes of the small businessman would be very materially alleviated.

${ }^{10}$ A summary of the plan is to be found in Journal of Commerce, April 25, 1945, p. 6, cols. 4, 5, 6. 


\section{Conclusion}

It seems quite clear that what we must seek is a radically new solution for the problems of financing small business, for a structure quite different from any that have been blue-printed as yet which will assure the needed flow of credits for short and medium term accommodations, and of long-term capital loans for the expansion of old and the establishment of new ventures. Our situation in this area of the domestic economy is not very different from that which we have already confronted in the field of foreign investment. There, it was realized, would be after the war a tremendous demand for United States capital, both for the reconstruction of devastated areas and for the development of backward and underindustrialized countries. And, there also, it was realized that the risks might be so high for our private bankers, and the costs so burdensome to the borrowers, that the needed and justified credits would not be forthcoming without the intervention of a public instrumentality. Therefore, the United States government has participated with the governments of the other United Nations in the establishment of the International Bank for Reconstruction and Development which has among its purposes, "when private capital is not available on reasonable terms, to supplement private investment by providing, on suitable conditions, finance for productive purposes out of its own capital."20 In other words it is one of the purposes of this Bank to make direct international loans when credit is either not available through the private banks or when it is only available at unreasonable cost. While the particular conditions of the domestic financial needs of small American enterprises do not parallel throughout those of foreign nations and their enterprises, there is enough similarity to provide an approach to the solution we have been looking for.

It is axiomatic that the maintenance of a high and balanced level of foreign trade and the success of international investment depend upon the sustaining of full production and employment in the United States. Small business is a big producer and a big employer. Small business can contribute handsomely to production, distribution and employment if it has the wherewithal to operate, if it is given access to credit and capital. This is what makes the problem of financing small business a national, even an international issue, regardless of the merits of its present situation. And it is these considerations which justify the assurance to small business of ready and reasonable access to the credit and capital resources of the nation. It is for these reasons, if for no other, that the financing of small business and the encouragement of its growth is an inescapable government responsibility. Small business, therefore, is entitled to credit not because it can give "reasonable assurances of repayment," but because its collective expansion will contribute to the health of a democratic world economy.

What is suggested here, frankly, is an outright subsidy to small business. We

${ }^{20}$ See Art. $x$ of Articles of Agreement of the International Bank for Reconstruction and Development, Annex B to United Nations Monetary and Financial Conference, Final Act and Related DocuMENTS (1945). 
have, in the past, made such a subsidy to encourage employment-because we recognized that widespread joblessness menaced the society in which we lived. We have, through the Farm Security Administration, subsidized the establishment of small independent farming units-because we recognized that rural democracy was threatened by the progressive concentration of power in large-scale, corporate agricultural establishments. We have, by one device or another, subsidized railroads, airlines, and a merchant marine-because we recognized that their development would be of benefit to our economy as a whole and to our national security. And through protective tariffs, we have conferred indirect subsidies on the very industries now grown so great that they threaten to cut the umbilical cord of nascent competition.

We know that we face in the United States a secular problem of providing full employment for our available manpower. We know, too, that we face a not unrelated problem of providing full opportunity for the exercise of individual initiative. Why not boldly couple these problems, make them reciprocal, and find a solution for one which will also help to solve the other? Expanding business is a key to full employment. Full employment, conversely, is indispensable to business health and expansion.

Let us establish an agency which will act to promote the security of small business-that is, make loans out of public funds, to productive enterprises which cannot obtain needed financing at reasonable rates through the private banking system. Let us altogether set aside in making these loans the test of "good business risk." Let us insist, instead, only upon the requirement that the enterprise give reasonable promise of promoting employment and adding to the social and economic wellbeing of the nation. Let us, within predetermined limits, make available to such enterprises, undertaken in good faith by men of character and competence, capital funds for the construction of new plants and facilities or for the expansion of existing establishments. The Farm Security Administration is a good illustration of the successful operation of just such an agency in a closely related field, that of small agricultural enterprise.

This proposal for direct governmental investment in small business is viewed as an implementation of the program for full production and employment set forth in a bill recently introduced by Senator James Murray of Montana. Senator Murray's bill provides that if projected private investment for a fiscal period should be inadequate to create full employment, a program of government investment would be authorized in connection with the annual budget in order to compensate for this inadequacy and to bring the total investment to the level required to create jobs for all. ${ }^{21}$ In all discussions of this project, public works have been emphasized as the appropriate sphere for government investment. It is here proposed that more

\footnotetext{
${ }^{31}$ For an analysis of this bill, see Gragg and Teale, The Proposed Full Employment Act (r945) 23 HARv. Bus. Rev. 323 .
} 
attention be directed to the allocation of a portion of the supplementary investment to be made by the Government to small business loans.

These loans must be for long terms, at low rates and with liberal refunding provisions if they are to meet the real small business need. They might well follow the pattern established for farm financing by the Farm Security Administration under which loans are made at 3 percent interest for periods not exceeding forty years to competent tenants, share-croppers, and farm laborers to enable them to become farm owners.'

The essential thing is to put the emphasis on need and to get away from the kind of restriction which makes the Reconstruction Finance Corporation, for example, just another bank. The R.F.C. is authorized to make loans to business enterprises for the purpose of promoting economic stability and employment. But all such loans must be, in the opinion of the board of directors "of such sound value, or so secured, as reasonably to assure retirement or repayment." Obviously, this renders the agency at once hors de combat with respect to high-risk financing. Its capital, at best, can be only slightly more venturesome than the capital of private bankers.

The criteria of lending must be changed. The only appropriate conditions for loans to small business which will genuinely enable it to grow are that they be needed for expansion or for undertaking new ventures, that they be used exclusively for these purposes, that they entail employment of manpower and that the applicant be a man of character unable to obtain the necessary funds on reasonable terms from private banking sources. It is essential, moreover, that the allocation of loans to small business be tied directly to the general program for full production and employment-not divorced from it in some administratively autonomous agency like the R.F.C. It will be necessary to liberalize or contract the extension of credit in direct ratio to the ebb and flow of national prosperity. When private investment is at a low level and when business and employment, in consequence, are diminishing-in a period, this is to say, when bankers are most reluctant to risk their capital-the Government must press vigorously for employment of its funds. When business is booming and private capital is inclined to seek investment opportunities, then Government lending must be minimized to avoid the danger of inflation. Government capital, in other words, must serve in the role of a mechanical governor to regulate the speed of the industrial machine-its function, balance; its purpose, constancy.

Assuming Congressional enactment of the Full Employment Bill, or something akin to it, we shall have an appropriation by Congress to supplement the estimated private investment when that estimate seems inadequate to generate full production and employment. Congress presumably will then determine how its appropriation should be used in the stimulation of private enterprise. Investment of the allocation to private enterprise within a designated fiscal period will consequently be mandatory. And the sole acceptable excuse for failure on the part of an administrator to 
invest the full amount allocated to him will be an insufficiency of loan applications from businessmen. The implications of such a contingency would be either that other governmental measures had so stimulated the flow of goods and services as to diminish the need for this part of the program or that private lending institutions had been sufficiently encouraged to undertake the needed financing.

This program would do something else as well-something of no negligible importance. It would help to bring back an all but forgotten art-character banking. In the days when there was faith in the American future, when bankers believed our economy to be infinitely, or at least indefinitely expansible, capital sought opportunity and knew that it could always find it in men of integrity, industry and intelligence. Such men were the "good business risks" of the era of expansion. Given the means and the opportunity, such men might well fulfill this role again. The men are not lacking; initiative is still a live part of the American heritage. The opportunity is waiting to be grabbed by the forelock; America is still an undeveloped continent in terms of its dreams and its potentialities. The means must be made available. ${ }^{22}$

${ }^{33}$ Since the foregoing pages were written, the Small Business Advisory Committee has submitted a report to the Secretary of Commerce embodying its recommendations on some of the problems of small business in the United States. Secretary Wallace in releasing this report for publication referred to it as "a magna carta for the small businessman." This report includes a brief section on Finance and Credit in which the Committee foresees the prospect of a substantial demand for long term funds by small businessmen. It also recognizes the fact that the present cost of equity financing is excessive and that such financing is difficult to obtain.

The Committee recommends the establishment of a government agency "to guarantee long term loans made by private financing institutions as a means of providing capital financing to new and established small business enterprises." The Committee also recommends the development of a special type of term loan for the long term financing of small business and particularly emphasizes the necessity for flexibility in amortization provisions. The report suggests that interest rates "should be as low as is consistent with economic conditions," that loans should run for 10 or 15 years and that current assets should not be required as collateral. It also proposes that a standard loan contract should be provided by the guaranteeing agency to incorporate these provisions. 